\title{
DAMIAN PAŁKA
}

\section{Konwertyci akatolicy w okresie międzywojennym. Studium pastoralno-historyczne na przykladzie archidiecezji poznańskiej}

Jedną z kwestii, które znajdowaly się w perspektywie przyszlej pracy duszpasterskiej księży, byla sprawa przechodzenia akatolików - glównie protestantów i prawoslawnych - na katolicyzm. Problematyka ta byla poruszana w podręcznikach teologii pastoralnej, które wprowadzaly alumnów seminariów duchownych w pracę w parafialna.

Zagadnienie to oraz jego praktyczna realizacja w ramach pracy duszpasterskiej w archidiecezji poznańskiej nie doczekaly się dotychczas swojego opracowania. Niniejszy artykuł stara się w jakiejś mierze wypelnić tę lukę i odpowiedzieć na dwa pytania: jak analizowano w podręcznikach teologii pastoralnej kwestię konwersji akatolików oraz, jak przedstawiala się praktyczna realizacja zaleceń pastoralistów w archidiecezji poznańskiej.

Ramy chronologiczne artykułu choć odnoszą się do okresu międzywojennego, swymi początkami sięgają roku 1874 , kiedy to ukazal się podręcznik teologii pastoralnej ks. Józefa Krukowskiego ${ }^{1}$. Stanowi on jeden z dziewięciu opracowań, które stały się podstawą źródłową do napisania niniejszego artykulu. Obok opracowania ks. Krukowskiego, analizie poddano podręczniki księży Mariana Biernackiego $^{2}$, Józefa Sebastiana Pelczara ${ }^{3}$, Karola Dębińskiego ${ }^{4}$, Alojzego Jougana ${ }^{5}$

\footnotetext{
${ }^{1}$ J. K r u k o w s k i: Teologia Pasterska katolicka dla użytku seminariów duchownych i pasterzów dusz. Wyd. 4. Kraków 1894.

${ }^{2}$ M. B i e r n a c ki: Teologia Pasterska wedlug ostatnich decyzyi Kongregacyi Rzymskich $i$ postanowień papieskich. Warszawa-Poznań 1911.

${ }^{3}$ J. S. P e l c z a r: Pasterz wedlug Serca Jezusowego czyli Ascetyka Pasterska. Lwów 1913.
} 
oraz Wilhelma Kloske ${ }^{6}$, które ukazaly się przed odzyskaniem przez Polskę niepodleglości. Spośród autorów, których glówna działalność pisarska przypadła na lata Polski Odrodzonej, wymienić należy prace księży Juliana Antoniego Nowowiejskiego7 oraz Wiktora Filipa Potempy ${ }^{8}$. W przededniu wybuchu drugiej wojny światowej ukazala się zbiorowa praca, pod redakcja ks. Zbigniewa Pilcha, która byla dziełem podsumowujacym dotychczasowe osiagnięcia polskich pastoralistów ${ }^{9}$.

Praktyczną realizację zasad dotyczących przechodzenia akatolików na katolicyzm, opracowano na podstawie materialów archiwalnych przechowywanych w Archiwum Archidiecezjalnym w Poznaniu w zespole Kurii Arcybiskupiej na przykładzie roku 1937.

Spośród prac traktujących o kwestiach zmiany religii wymienić należy przede wszystkim monografię Krzysztofa Lewalskiego, który analizował konwersje wyznawców judaizmu na lono katolicyzmu, ale również innych kościolów chrześcijańskich. Autor ten jako pierwszy wykorzystal w swoich badaniach wskazania teologii pastoralnej, analizując wspomniany już podręcznik ks. Krzysztofa Krukowskiego. Niestety zawężony chronologicznie i terytorialnie temat monografii, nie pozwolił na szersze potraktowanie problematyki ${ }^{10}$.

Osobny artykul poświęcony kwestii żydowskich konwertytów w podręcznikach teologii pastoralnej wyszedł spod pióra piszacego te slowa. Autor staral się dać w nim odpowiedź na dwa pytania: jak wyglądal obraz Żyda w polskich podręcznikach teologii pastoralnej oraz jak należalo postępować z żydowskimi konwertytami ${ }^{11}$.

${ }^{4}$ K. Dę biń ski: Podręcznik Praktyczny Teologii Pasterskiej. T. I-II. Warszawa-LublinLódź 1914.

${ }^{5}$ A. J o u g a n: Podręcznik teologii pasterskiej wedle najpoważniejszych autorów i nowszych orzeczeń kongregacyi. Lwów 1917.

${ }^{6}$ W. K 1 o s k e: Pastoralna. Gniezno 1914-1918.

${ }^{7}$ A. J. N ow ow i j sk i: Pastorologia. Wyd. II. Płock 1930.

${ }^{8}$ W. F. P o te m pa: Więcej psychologii w duszpasterstwie czyli: Teologia Pasterska w świetle psychologii. Wlocławek 1938.

${ }^{9}$ Nauka pasterzowania. Red. Z. Pilch. T. 1. Kielce 1939.

${ }^{10} \mathrm{~K}$. L e wa lsk i: Kościoly chrześcijańskie wobec Żydów w Królestwie Polskim w latach 1855-1915. Kraków 2002.

${ }^{11}$ D. P a $1 \mathrm{k}$ a: Żydzi w polskich podręcznikach teologii pastoralnej. „Teologia Praktyczna”. R. 2004: 5 s. 119-132. 
Na uwagę zashuguje również artykul A. Penkali, który traktuje o problematyce zmiany religii wśród Żydów w guberni radomskiej w okresie lat 1867$1914^{12}$.

\section{Akatolicy w Wielkopolsce w okresie międzywojennym. Rys historyczny}

Jednym $z$ istotnych problemów spolecznych i politycznych Polski międzywojennej byla obecność na ziemiach nowoutworzonego państwa mniejszości narodowych i wyznaniowych. Zachodnie jego części zamieszkiwali Niemcy, których obecność charakteryzowala się zaangażowaniem w życie religijne w ramach Kościołów i wspólnot protestanckich. Po rozejmie trewirskim i podpisaniu przez Polskę traktatu wersalskiego ludność niemiecka obszarów przejętych przez państwo polskie stanęla przed wyborem egzystencji na ziemiach polskich ze statusem mniejszości narodowej, badź emigracji do Republiki Weimarskiej. W latach 1919-1921 z Wielkopolski i Pomorza, w mniejszym zakresie ze Ślaska, wyjechało dobrowolnie ok. 650 tys. osób narodowości niemieckiej. Ponadto do 1926 r. Wielkopolskę i Pomorze opuścilo kolejne 250 tys. Niemców, a Ślassk okolo 100 tys. Wedlug danych II spisu powszechnego z 1931 r. na terenie Polski mieszkalo ok. 714 tys. Niemców. Dane szacunkowe polskich badaczy oscyluja wokól liczby 750-900 tys., natomiast statystyki niemieckie zamykają się cyfrą ok. 1 miliona ${ }^{13}$.

W okresie dwudziestolecia na terenie Wielkopolski funkcjonowaly trzy kościoly protestanckie. Oprócz najstarszego i najliczniejszego Kościoła Ewangelicko-Unijnego, dzialał także Kośció Ewangelicko-Luterański (zwany również staroluterańskim) oraz Kościól Ewangelicko-Augsburski, który rozpoczał swą działalność w tym regionie w $1919 \mathrm{r}$.

Ostatni spis ludności, który odbył się w Prusach przed wybuchem I wojny światowej, wykazal, że ludność ewangelicka stanowila znaczny odsetek mieszkańców Wielkopolski. Zamieszkiwalo ją 653417 ewangelików niemieckiej narodowości oraz 9333 ewangelików Polaków. Wśród ogólnej liczby Niemców ewangelikami było niemal $81 \%$ osób tej narodowości. Kompetencje zakresu dzialalności Kościola Ewangelicko-Unijnego oraz funkcjonowania jego gmin precyzowaly pruskie przepisy z 10 września $1873 \mathrm{r}$. oraz 25 stycznia $1882 \mathrm{r}$.,

${ }^{12}$ A. P e $\mathrm{n} \mathrm{k}$ a $11 \mathrm{a}: Z$ problematyki zmiany wyznania wśród Żydów na terenie guberni radomskiej w latach 1867-1914. W: Naród i religia. Materialy z sesji naukowej. Red. T. S t e g n e r. Warszawa 1994.

${ }^{13}$ H. C h a 1 u p c z a k, T. B row are k: Mniejszości narodowe w Polsce 1918-1995. Lublin 1998 s. 125. 
które w odrodzonej Polsce zostaly potwierdzone ustawą z dnia 1 sierpnia $1919 \mathrm{r}$. W okresie pruskim na czele ewangelicko-unijnego kościoła krajowego stal król pruski. Urzędem centralnym byla Naczelna Rada Kościelna (Evangelischer Oberkirchenrat) w Berlinie. W każdej z pruskich prowincji istnial konsystorz podporzadkowany Radzie Naczelnej. Obszar podlegly konsystorzom dzielił sie na diecezje. Na czele diecezji stali superintendenci. Konsystorz dla Prus Zachodnich miał swą siedzibę w Gdańsku, a dla Wielkopolski w Poznaniu. Oczywiście taki ustrój nie był możliwy do utrzymania w momencie wlączenia Wielkopolski i Pomorza do państwa polskiego. Jak zauważa Przemyslaw Hauser dążc do zjednoczenia pod wspólnym kierownictwem Kościola Ewangelicko-Unijnego na terytoriach przyjętych przez Polskę, Naczelna Rada Kościelna w Berlinie w dniu 11 maja 1920 roku postanowila podporzqdkować tereny województwa poznańskiego i pomorskiego konsystorzowi w Poznaniu. Ponieważ wladze polskie ówczesnego Ministerstwa bylej Dzielnicy Pruskiej w swoim rozporzqdzeniu zajęly identyczne stanowisko $w$ tej kwestii, decyzja podjęta w Berlinie zostala wykonana bezkoli-

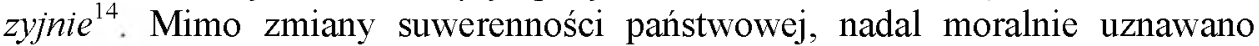
Berlin za siedzibe wladz naczelnych Kościola Ewangelicko-Unijnego także dla obszarów przejętych przez Polskę, a przedstawiciele kościola z Poznańskiego i Pomorza byli zapraszani jako goście na synody generalne w Berlinie. Oczywiście władze Polski zachodniej tej sytuacji nie mogly zaakceptować i oczekiwaly uregulowania wzajemnych stosunków.

Emigracja ludności niemieckiej po przylączeniu terenów bylego zaboru pruskiego do Polski przyczynila się do znacznego uszczuplenia stanu liczebnego ewangelików-unijnych na tych terenach. W świetle danych I spisu powszechnego z września $1921 \mathrm{r}$. województwo poznańskie zamieszkiwalo 322878 ewangelików. Przeprowadzony sześć lat później spis wiernych, wykazal spadek ich liczby do 200595 osób. W świetle danych II spisu powszechnego z 1931 r. Wielkopolskę zamieszkiwalo 197571 ewangelików unijnych, z których 29893 osób podalo język polski jako ojczysty, co stanowiło $15,1 \%$ wszystkich wyznawców Kościoła ewangelicko-unijnego w Wielkopolsce. Wraz z reorganizacją granic województwa 1 kwietnia 1938 r., doszlo do dalszego spadku liczby wiernych tego Kościola, a przeprowadzony w styczniu 1939 r. spis wykazal 142719 osób tego wyznania $^{15}$.

${ }^{14}$ P. H a u s e r: Mniejszość niemiecka na Pomorzu w okresie międzywojennym. Poznań 1998 S. $156-157$

${ }^{15}$ D. Matel s k i: Mniejszość niemiecka w Wielkopolsce w latach 1919-1939. Poznań 1997 s. 214-232.; S. T u ro w s k i: Kościól Ewangelicko-Unijny w Polsce 1920-1939. Bydgoszcz 1990 s. 60.; R. D a b ro w s k i: Mniejszość niemiecka w Polsce i jej dziatalność spoleczno-kulturalna w latach 1918-1939. Szczecin 1982 s. 67. 
Kościół Ewangelicko-Luterański, działający na podstawie rozkazu gabinetowego króla pruskiego Fryderyka Wilhelma III z 27 września 1817 r., w Polsce międzywojennej funkcjonowal na mocy ustawy z 1 sierpnia 1919 r., która potwierdzała wcześniejsze przepisy. Umożliwilo to powolanie do życia diecezji ewangelicko-luterańskiej, na której czele jako superintendent stanął Reinhold Büttner z Rogoźna. Tam też znajdowała się siedziba Zarządu Glównego wspólnoty. Kościól Ewangelicko-Luterański zrzeszal niewielką grupę ludności niemieckiej. Dane spisowe z 1910 r. wspominają o 8 tys. wyznawców w Prowincji Poznańskiej, co stanowilo niespelna 1 procent zamieszkalych tutaj Niemców $(0,99 \%)$. Spisy kościelne przeprowadzone w latach dwudziestych i trzydziestych wykazaly, iż staroluteran w 1923 r. było 4154, a w 1938 ok. 3700. Charakter Kościola był w 99\% niemiecki, a większość jego wyznawców mieszkala na wsi. Największym skupiskiem wiernych pozostawal w okresie międzywojennym Poznań, w którym mieszkalo w 1921 r. 339 wiernych, a dwa lata później - w związku z wlączeniem wiernych z sześciu polskich miejscowości $-551^{16}$.

Ostatni z Kościolów protestanckich - ewangelicko-augsburski - w okresie zaborów funkcjonowal wśród ludności niemieckiej na terenach Królestwa Polskiego. W Wielkopolsce nie posiadal swojej struktury. Prawne uregulowanie podstaw dzialalności Kościoła nastapilo dopiero dekretem prezydenta Ignacego Mościckiego z 25 października 1936 r. oraz nadaniem konstytucji wewnętrznej z 17 grudnia tego samego roku. Od lat dwudziestych na terenie Wielkopolski dzialały dwa zbory ewangelicko-augsburskie z siedzibami w Poznaniu i Bydgoszczy. Według II powszechnego spisu ludności z $1931 \mathrm{r}$. na terenie województwa poznańskiego mieszkalo 5485 ewangelików augsburskich, zaś w utworzonej w 1937 r. nowej diecezji wielkopolskiej mieszkalo 10130 wiernych tego Kościola, w tym 7530 Niemców (74,3\% ogólu wiernych) oraz 2600 Polaków (25,7\%). Stan liczebny ewangelików augsburskich na terenie województwa zwiększyl się w 1938 r., po przylączeniu diecezji kaliskiej ${ }^{17}$.

Zupelnie inny problem stanowila obecność w Wielkopolsce wyznawców prawosławia. W Polsce przedwrześniowej cerkiew prawosławna skupiała ponad 3,8 miliona wyznawców, z czego 1,5 miliona stanowili Ukraińcy, 900 tys. Bialorusini, 700 tys. tzw. „tutejsi”, 600 tys. Polacy oraz 125 tys. Rosjanie. Na stan organizacyjny cerkwi składało się 5 diecezji i ok. 1500 parafii. Większość wyznawców prawosławia zamieszkiwalo na ziemiach bylego zaboru rosyjskiego. W dzielnicy popruskiej mieszkało ok. 3 tys. prawoslawnych którzy posiadali parafie w Bydgoszczy i Toruniu z filią w Grudziądzu oraz cerkiew wojskową w Poznaniu. W bylym zaborze austriackim mieszkalo ok. 8400 prawoslawnych, którzy

${ }^{16}$ D. Mate 1 sk i, dz. cyt., s. 232-235.

${ }^{17}$ B. K u mo r: Historia Kościola. Część 8. Czasy wspótczesne 1914-1992. Lublin 1996 s. 427-428.; D. Mate l s k i, dz. cyt., s. 237-241. 
korzystali z jednej tylko cerkwi we Lwowie oraz kaplic wojskowych w Krakowie i Przemyślu ${ }^{18}$.

\section{Prawne podstawy udzielania chrztu akatolikom}

W świetle wskazań teologii pastoralnej duszpasterze mieli zachowywać $z$ chrześcijanami innych wyznań pokój i zgodę w sassiedzkim obcowaniu. Nie powinni przeszkadzać $\mathrm{w}$ nabożeństwach, ani w żaden sposób prześladować innowierców, aby w ten sposób nie ściagnać nienawiści względem religii katolickiej. Jednocześnie zabronione bylo katolickim duchownym zastępowanie pastora $\mathrm{w}$ jego funkcjach kościelnych ${ }^{19}$. Ksiądz Józef Sebastian Pelczar tak pisal na ten temat: Z jednej strony nie wkraczaj w ich prawa i swobody, nie gloś przeciw nim krucyaty, nie budź nienawiści do nich, ale oddawaj im to wszystko, czego mitość $i$ sprawiedliwość chrześcijanska wymaga. $Z$ drugiej badź dalekim od tolerancji dogmatycznej, która, jako płód indyferentyzmu, kladzie bląd na równi z prawda. (...) Potępiajac takq tolerancję, wykladaj czasem gruntownie ten dogmat: "Extra Ecclesiam non est salus«; mów z zapalem o blogostawieństwach, jakie sprowadza religia katolicka, i roztropnie stodko pociagaj bladzqcych na droge prawdy. W opinii biskupa przemyskiego księża mieli ostrzegać parafian przed braniem udzialu w życiu religijnym akatolików, chociaż odprowadzenie zwlok protestanta na cmentarz nie było zakazane. Natomiast niewłaściwe bylo czytanie akatolickich książek, posyłanie dzieci do wspólnych szkól i zawieranie ślubów, albowiem jak przekonywal, małżeństwa mieszane rzadko wychodzily stronie katolickiej na dobre. Dlatego też, gdy ta strona jest mocno utwierdzona w wierze, $i$ przyrzeka, że stronę protestancka przyciagać będzie do Kościoła, można by na podobny zwiqzek bezpiecznie się zgodzic ${ }^{20}$.

Pastoraliści dawali jasne wskazania dotyczące postępowania z osobami pragnącymi przejść na katolicyzm a będącymi już chrześcijanami. Wobec takich osób księża winni wykazać „radość i gotowość do dania rady”. Po zbadaniu pobudek przejścia na lono Kościola katolickiego, gdy okazaly się one czyste, należalo zapytać konwertytę o dane osobowe (imię, nazwisko, wiek, stan cywilny, miejsce pobytu, stosunki rodzinne i majątkowe, a także o „inne okoliczności” dotyczace np. uregulowania obowiazku shużby wojskowej). Dalszy etap sprawdzenia kandydata polegal na uzyskaniu informacji co do prowadzenia się prozelity, o którego moralności mogli na piśmie wypowiedzieć się świadkowie. Ksiądz rozpatrujacy prośbę petenta mógl pisemnie prosić o wyrażenie swojej opinii

\footnotetext{
${ }^{18}$ K. K r a s o w sk i: Zwiqzki wyznaniowe w Drugiej Rzeczypospolitej. Studium historycznoprawne. Warszawa-Poznań 1988 s. 106-107.

${ }^{19}$ J. Kruk ow ski, dz. cyt., s. 671.

${ }^{20}$ J. S. P e l c z a r, dz. cyt., s. 415-417.
} 
przez urząd gminy, na terenie której zamieszkiwal. Osobie znanej ze złego prowadzenia się, bądź czerpiącego zyski z niegodziwego źródla należalo odmówić konwersji, do momentu poprawy. Jeżeli żadna przeszkoda nie zostala odkryta wówczas należalo przychylić się do prośby petenta. Jeżeli ten nie mialby możliwości pozostawania poza wplywami akatolików należalo wyszukać dla niego „uczciwy dom”, lub umieścić go w klasztorze, gdzie można bylo uczyć go rzemiosla, jeżeli był ubogi. przede wszystkim jednak, aby z dobrego przykladu gospodarzów zaprawial się do życia katolickiego i praktyk religijnych ${ }^{21}$.

Przed glównym nauczaniem prawd wiary katolickiej, należało wypytać petenta $z$ jakiego wyznania zamierzal przejść na lono katolicyzmu, wybadać czy jest „,czlowiekiem nauki, czy światlym, lub uczonym” oraz przekonać się o stopniu jego wiedzy religijnej. Dopiero na dalszym etapie należalo konwersa nauczyć prawd wiary katolickiej, modlitwy, a także przedstawić katolickie obrzędy kościelne. Ponadto należalo uprzedzić o niechęci, jaka mogla go spotkać ze strony dawnych wspólwyznawców. Przygotowanie do spowiedzi i Komunii św. kończyło okres przygotowawczy. Należało także zwracać uwagę na zachowanie konwersa w trakcie przygotowania i potępiać szydzenie neofity $z$ dawnej wiary, a samemu zachować lagodność i nie potępiać innowierców, to bowiem mogloby nadwerężyć jego zaufanie. Watpliwości należalo wyjaśnić, a postawione zarzuty roztropnie odeprzeć. W razie konieczności wskazać wlaściwą literaturę, która konwersowi pomogłaby w przygotowaniu ${ }^{22}$.

Czas przygotowania zostal przewidziany na 5-6 tygodni, a uzależniony byl od tego czy nauka odbywala się raz czy dwa razy w tygodniu. W naglych przypadkach można było czas przygotowania skrócić do kilku dni, a resztę nauki dopelnić już po przyjęciu do Kościola. W wypadkach bliskiej śmierci, gdy nie bylo czasu odnieść się do biskupa, duszpasterz powinien odebrać od umierającego wyznanie wiary przy dwóch świadkach i zaopatrzyć go w sakramenty ${ }^{23}$.

Jak przekonywał ks. Alojzy Jougan, dla pomyślnego przebiegu konwersji nie wystarczalo jednak samo nauczanie prawd wiary, należało również wprowadzić „wychowanie kościelne”, które zaprawialoby konwertytę do żarliwej modlitwy o nawrócenie, do przeświadczenia, że do wiary potrzebna jest także pomoc laski. Należało zachęcać do czytania książek katolickich, traktujacych o różniących prawdach wiary, bądź żywoty nawróconych. Troskę nad konwertytami należało rozciagnąć także poza okres samej konwersji, dlatego duszpasterz powi-

${ }^{21}$ J. Kruk ow ski, dz. cyt., s. 683.

${ }^{22}$ Również podręcznik ks. Alojzego J o u g a n a nakazywał, by unikać ,sadów ostrych o innowiercach", zaś prawdy wiary należalo tak wykładać, by wiele miejsca poświęcić artykułom różniącym, a przy tym położyć nacisk na „powagę i nieomylność Kościola” (A. J o u g a n, dz. cyt. s. 1062-1064).

${ }^{23}$ J. S. P el c z a r, dz. cyt., s. 417. 
nien pozostawać z nimi w kontakcie, wyjaśniać ewentualne watpliwości, zachęcać do częstego uczęszczania na nabożeństwa, do przyjmowania sakramentów. Przy spowiedziach początkowych uzupelniać ich wiadomości religijne i dokladnie pouczać, jak maja wypelnić zadaną pokutę ${ }^{24}$. Dobry wplyw wywierało się także za pomoca odwiedzin, przyjaznych stosunków oraz staraniem o chorych ${ }^{25}$.

Obrzęd konwersji mógl zostać przeprowadzony po uzyskaniu od biskupa wladzy absolwowania od herezji. Zazwyczaj uroczysta konwersja odbywala się podczas mszy świętej w niedzielę, lub święto, chyba że konwers sobie tego nie życzyl. Kaplan w fioletowej stule, odmawiając psalm 50, wprowadzal konwersa od drzwi kościelnych. U progu oltarza zwrócony do wiernych odczytywał wyznanie wiary katolickiej, a konwertyta, jeżeli nie umial czytać, trzymając zapaloną świecę, powtarzał w obecności dwóch świadków treść wyznania wiary. Jeżeli umial czytal sam, po czym kładł rękę na Ewangelii i wypowiadal słowa przysię$\mathrm{gi}^{26}$. W tym czasie kaplan uwalnial konwertytę od herezji, po czym następowała spowiedź, chrzest warunkowy - jeżeli zachodziło podejrzenie co do jego ważności - oraz Komunia święta. Całość obrzędu kończyła krótka przemowa duszpasterza, który polecal konwertytę „milości bratniej katolików” i zachęcal do dziękczynienia za nawrócenie. Należalo jeszcze zapisać go do osobnej księgi z podpisami konwersa i dwóch świadków, albo do księgi urodzonych i zdać sprawę kuriii ${ }^{27}$.

Co do kwestii ważności chrztu informuje nas podręcznik pióra ks. Mikołaja Biernackiego, który wykazywal, iż za nieważny należy uznać chrzest udzielony przez skropienie glowy perfumami, wodą różana, lub innymi podobnymi specyfikami, które bylyby mieszanina wody $\mathrm{i}$ innych substancji ${ }^{28}$. Zauważyl ponadto, iż niektóre wyznania protestanckie stosowaly się do tej praktyki, dlatego należalo tak przeprowadzony chrzest powtórzyć. Takiego powtórzonego chrztu nie udzielało się już jednak jawnie, ale secreto w zakrystii ${ }^{29}$, a konwertytę należało najpierw upomnieć, aby wzbudzil w sobie żal za popelnione winy, a po chrzcie wyspowiadać z calego życia $\mathrm{i}$ warunkowo udzielić rozgrzeszenia. W trudniejszych wypadkach należalo udać się do kurii biskupiej po wskazówki jak należy postąpić $^{30}$.

${ }^{24}$ A. J o u g a n, dz. cyt., s. 1062-1064

${ }^{25}$ A. Now owi e j s ki, dz. cyt., s. 356.

${ }^{26}$ Przykładowe teksty przysiegi zob. aneksy $1-3$.

${ }^{27}$ J. Kruk ow ski, dz. cyt., s. 684-685.

${ }^{28}$ Woda do chrztu winna być czysta, naturalna, zimna lub ciepla, destylowana a nawet mineralna, rzeczna, studzienna. Jako materię watpliwa uważa się wszystko to, co jest plynne i jest mieszanina wody i innych substancji (M. B i e r n a c k i, dz. cyt., s. 66-67).

${ }^{29}$ Podobnie zob.: K. Dę b iń s k i, dz. cyt., s. 10-11.

${ }^{30}$ M. B i ernacki, dz. cyt., s. 69-70. 
Kolejne istotne zalecenia odnoszace się do przyjmowania innowierców na lono Kościoła katolickiego znajdujemy w podręczniku ks. Filipa Wiktora Potempy, który odniósł się do możliwości konwersji protestantów. Oceniał je jako nikle, albowiem - jak przekonywal - próby nawrócenia protestantów mogly mieć powodzenie, tylko jeśli chodzilo o osoby niezadowolone ze swej religii. Jednocześnie za zle uznawal postępowanie zmierzajace do „obrzydzania” przez duchowieństwo katolickie religii protestanckiej, ponieważ innowierca mógł zostać zbawiony, o ile trwa $w$ blędzie bez swej winy $i$ żyje wedlug swych przekonań. Ponadto należało pamiętać i o tym, że nie było pewności co do tego, iż po podkopaniu fundamentów wiary protestanckiej udałoby się taką osobę przeprowadzić na łono katolicyzmu. $Z$ tego też powodu wiara falszywa w niektórych wypadkach może być lepsza od braku wszelkiej wiary - przekonywal. Rozważając szczególowo kwestię możliwości nawrócenia protestantów w Polsce, ks. Potempa zauważył, iż głównym czynnikiem, dla którego nie nawracali się oni na katolicyzm, było skorelowanie przez pastorów protestantyzmu z językiem niemieckim, którym poslugiwali się przy nabożeństwach. Ich trzyma nie tyle wiara, ile niemiecki język - konkludowal, a swoje przekonanie ilustrowal przykładem Polaków, których przywiązanie do polskości wiązało się z językiem i religią katolicka. Z tego ścislego zwiazku - pisal - pomiędzy religiq a językiem wynika, że widoki nawrócenia protestantów w Polsce na razie nie istnieja. Dopóki protestanci polscy będq krzewili język niemiecki w szkole $i$ w kościele, masowe nawrócenie się protestantów w Polsce nie nastapi nigdy ${ }^{31}$.

W dalszej części swej pracy ks. Potempa rozważal możliwość nawrócenia ludności prawosławnej, które postrzegal jako znaczne, albowiem część tej ludności zamieszkującej II Rzeczpospolitą należała wcześniej do obrządku unickiego, który wladze carskie zlikwidowaly. Kościól katolicki staral się ulatwić bylym unitom powrót na lono katolicyzmu poprzez pozostawienie slowiańskiej liturgii. Ponadto dzialalność cerkwi prawosławnej w Polsce oparta byla na dużo gorszych podstawach gospodarczych niż Kościola katolickiego, na co wplyw mialy m.in. małżeństwa popów, których utrzymanie bylo trudniejsze, niż żyjących bez rodziny katolickich księży. Przeszkodą w nawracaniu prawoslawnych miała być grecka kultura i język ruski, a także wcześniejsza dzialalność polityczna państw zaborczych, zwłaszcza Austro-Węgier, które dążyły do podzielenia Polaków i Rusinów, popierajac ukraińskie aspiracje narodowe, które wiązaly się z cerkwią greckokatolicką ${ }^{32}$.

\footnotetext{
${ }^{31}$ W. F. P o te m p a, dz. cyt.., s. 173-174.

32 Tamże, s. 174-175.
} 


\section{Praktyka udzielania chrztu akatolikom w archidiecezji poznańskiej}

Najmniej wątpliwości budzily konwersje osób przechodzących na katolicyzm z prawosławia. W większości wypadków procesy te trwaly krótko i zakończyly się pomyślnie. Jedyne przeszkody, na jakie natrafiali petenci, związane byly z niemożliwościa zaświadczenia o chrzcie przyjętym w cerkwi prawosławnej. Wiazzalo się to niejednokrotnie z pośpiesznym opuszczaniem terenów państwa rosyjskiego, wraz z postępującymi sukcesami bolszewików w okresie rewolucji. Przybywające do Wielkopolski osoby niejednokrotnie pozbawione byly dokumentów, a także zaświadczeń potwierdzających chrzest. Jeżeli nie znaleziono osób mogących poświadczyć na rzecz konwersa, wówczas następowalo warunkowe powtórzenie chrztu ${ }^{33}$.

W 1937 r. miało miejsce 18 konwersji osób pochodzacych z prawosławia. W jednym wypadku przejścia na łono Kościoła katolickiego dokonali wspólnie małżonkowie. W jednym wypadku konwersja odbyla się w tajemnicy, albowiem konwertytka uchodzila za katoliczkę w swoim otoczeniu i prosila, poprzez księdza prowadzącego sprawę, o dyskretne jej przeprowadzenie. Należy zaznaczyć, iż najczęstsza przyczyna zmiany wyznania wśród prawosławnych byla chęć uregulowania kwestii związanych z małżeństwem. Na ogólną liczbę 18 konwersji z prawoslawia 11 przypadków dotyczylo kobiet a 7 mężczyzn.

Największa liczba konwersji w archidiecezji poznańskiej w 1937 r. związana jest $z$ protestantyzmem. Niestety nie sposób ustalić $z$ jakich kościolów protestanckich pochodzili konwertyci, albowiem księża prowadzący sprawę wpisywali jedynie dwie informacje określające przynależność religijną petenta. Używali słów protestant, lub ewangelik, bez jasnego sprecyzowania przynależności do jednego $\mathrm{z}$ trzech dzialajacych na terenie Wielkopolski kościolów protestanckich. $\mathrm{Na}$ ogólną liczbę 81 procesów konwersji, 51 dotyczyło kobiet, a 30 mężczyzn. W trzech przypadkach chęć zmiany religii motywowana byla wprost chęcia zawarcia ślubu z osobą, która byla wyznania katolickiego. Jedna z konwersji objęła dwoje malżonków, również jeden raz konwertowala matka z dzieckiem.

Najistotniejszym problemem wynikającym z konwersji protestantów byla, kwestia ponownego udzielenia chrztu w formie warunkowej. Na 81 procesów, 54 zakończyly się powtórnym chrztem, przy tym należy pamiętać, iż nie zawsze księża dokonujacy konwersji informowali kurię arcybiskupia o odbytym chrzcie. Jedynie sporadycznie pojawiaja się informacje, w których mamy jasne określenie, iż przyjęty w zborze protestanckim chrzest uznany zostal za ważny.

${ }^{33}$ AAP, KA, sygn. 3466, Sprawa konwersji Agaty R o b iń s k i e j, nlb. 
Wśród miejsc, w których dokonywano aktów konwersji wymienić można trzy: kościól parafialny, zakrystię oraz kaplicę zgromadzenia zakonnego. W jednym wypadku osoba przechodząca na lono Kościola katolickiego pochodzila spoza diecezji. Sporządzone protokoly konwersji, przesłane zostaly do kurii arcybiskupiej w Poznaniu oraz do proboszcza osoby zmieniajacej wyznanie. W 1937 r. dokonano także jednej konwersji na łożu śmierci, a umierającego zaopatrzono w namaszczenie olejami oraz udzielono odpustu zupełnego w godzinę śmierci. Chrztu w tym wypadku nie powtórzono ${ }^{34}$.

Glównym rezerwuarem, z którego rekrutowali się wyznawcy protestantyzmu, byli mieszkający w Wielkopolsce Niemcy. Oczywiście część polskiego spoleczeństwa również należala do jednego z trzech dzialających na terenie Wielkopolski kościolów protestanckich, jednakże źródla archiwalne nie pozwalają ustalić przynależności kościelnej konwertytów, albowiem tylko w sporadycznych przypadkach pojawialy się określenia dotyczące przynależności religijnej.

Z kolei obecność wyznawców prawoslawia w Wielkopolsce byla wlaściwie symboliczna, albowiem dysponowali oni zaledwie kilkoma obiektami kultu religijnego, w tym jedną cerkwią wojskową w Poznaniu.

Najczęstszym powodem konwersji wśród akatolików byla chęć uregulowania spraw życia malżeńskiego, bądź zawarcia malżeństwa $z$ katolikiem. W niektórych wypadkach wladze kościelne pozwalaly duszpasterzom dokonać konwersji zaledwie po kilku dniach od wplynięcia do kurii pisma wszczynającego sprawę konwersji.

Istotna kwestia, która nie znalazla odzwierciedlenia $\mathrm{w}$ artykule pozostaje opieka nad konwertytami, jaką duszpasterze rozciagali w swojej parafii. Z braku materialów archiwalnych nie sposób ustalić, czy byla ona podejmowana także po okresie konwersji i do jakich sprowadzala się poczynań.

Pytaniem równie istotnym pozostaje kwestia stosunków w ramach wspólnoty wiernych, albowiem niejednokrotnie dochodzilo w diecezji do rywalizacji pomiędzy katolikami Niemcami a Polakami ${ }^{35}$. Nie sposób dzisiaj

34 AAP, KA, sygn. 3466, Sprawa konwersji Stefana M ü 11 e r a, nlb.

${ }^{35} \mathrm{Na}$ temat działalności niemieckich katolików w dekanacie czarnkowskim zob. D. P a lk a: Spoleczeństwo Czarnkowa w latach 1919-1939 w świetle Archiwum Archidiecezjalnego w Poznaniu. W: Pamiętnik III Ogólnopolskiego Zjazdu Studentów Archiwistyki w Lublinie. Red. J. S z y $\mathrm{m}$ a ń sk i. Lublin 2001. Niestety kwestii tej nie podejmuje w swej monografii Zygmunt Z i e li í - 
ustalić, w jaki sposób katolicy Polacy traktowali przechodzących na lono Kościola Niemców, czy Żydów, a zagadnienie to wciąż czeka na zbadanie.

\section{Aneksy}

\section{Aneks 1}

Tekst przysięgi złożonej w trakcie konwersji ${ }^{36}$.

$\mathrm{Ja}$ ur.

i ochrzczony w cerkwi prawosławnej w wyrzekłem się dzisiaj dobrowolnie schizmy i wrócilem na lono Kościoła katolickiego. Krok ten uczynilem po dokladnym namyśle i przyrzekam uroczyście, że wszelkich sil dolożę, by być wiennym synem Kościoła katolickiego i wszystkie przyjęte obowiązki dobrze wypehnić".

\section{Aneks 2}

Tekst przysięgi zlożonej w trakcie konwersji ${ }^{37}$.

„Ja ...................... wierzę mocno i wyznaję każdą prawdę z osobna i razem wszystkie prawdy, jakie się zawierają w Skladzie Wiary, którego używa święty Kościół Rzymski".

\section{Aneks 3}

Tekst przysięgi zlożonej w trakcie konwersji ${ }^{38}$.

Ja syn majac lat klęknąwszy wobec ciebie ks. Wikariuszu ................................, mając przed sobą Ewangelię świętą i dotykając się jej swoją ręka, wyznaję swoje przekonanie, w to że nikt nie może osiagnać zbawienia wiecznego, jeżeli nie wierzy w to, co otrzymuje i w co wierzymy, co glosi i czego naucza święty apostolski Kościół Rzymskokatolicki. Żahuję żem przeciw tej wierze ciężko blądzil, gdyż urodzony poza tym Kościolem utrzymywalem i wierzylem w blędy jego nauce przeciwne.

Teraz laską Bożą oświecony, oświadczam, iż wierzę, że święty katolicki i apostolski Kościól Rzymski jest tym jedynie prawdziwym Kościolem, który Jezus Chrystus na ziemi ustanowi1. Temu Kościołowi z całego serca się poddaję. Wierzę we wszystkie prawdy, które on do wierzenia podaje, odrzucam i potępiam, cokolwiek on odrzuca i

sk i. Zob. Z. Zi e li ńs ki: Katolicka mniejszość niemiecka w Wielkopolsce i na Pomorzu 19181939. Poznań 2001.
${ }^{36}$ AAP, KA, sygn. 3452, Sprawa konwersji Mikolaja P o d o l a k a.
${ }^{37}$ AAP, KA, sygn. 3452, Sprawa konwersji Jana C i e ś 1 i.
${ }^{38}$ AAP, KA, sygn. 3452, Sprawa konwersji Stefana S m u r a g i 
potępia, i gotów jestem zachowywać wszystko cokolwiek mi nakazuje. W szczególności zaś wyznaję:

Wierzę, że jedne jest tylko Bóg w trzech różnych, a równych sobie osobach, mianowicie w osobach Ojca, Syna i Ducha Świętego. Przyjmuję katolicką naukę o wcieleniu, Męce, śmierci i Zmartwychwstaniu Pana naszego Jezusa Chrystusa; wierzę w zjednoczenie istotne dwóch natur, boskiej i ludzkiej w Panie Jezusie, w boskie Macierzyństwo najświętszej Marii Panny, oraz w jej nienaruszone Panieństwo i niepokalanie Poczęcie.

Wierzę w prawdziwa, rzeczywistą i istotną obecność ciała razem z Duchem i Bóstwem Pana naszego Jezusa Chrystusa w Najświętszym Sakramencie Eucharystii. Przyjmuję siedem Sakramentów świętych, ustanowionych przez Jezusa Chrystusa dla zbawienia ludzkiego, mianowicie Chrzest, Bierzmowanie, Eucharystię, Pokutę, Ostatnie Namaszczenie, Kaplaństwo i Małżeństwo.

Wierzę w Czyściec, Zmartwychwstanie, Żywot wieczny.

Uznaję, że Biskup Rzymski, następca świętego Piotra, księcia Apostołów i Nieomylny Namiestnik Jezusa Chrystusa, ma nie tylko czci pierwszeństwo, lecz i najwyższą władzę w Kościele.

Oddaję cześć oddawaną świętym, oraz ich obrazom.

Wierzę w to, co Apostolowie przekazali, a Kościól do wierzenia podaje, oraz w Pismo Święte, które rozumieć i wykladać godzi się tylko w tem znaczeniu, jakiego się trzymał i trzyma święta matka Kościół katolicki. Wierzę również we wszystko, co przez święte Kanony i Sobory powszechne, a zwłaszcza przez święty sobór Trydencki i Watykański, zostało określone i wyjaśnione. Przeto sercem i z wiarą nieudawaną odrzucam i wyrzekam się wszelkich błędów, herezji i sekt, które są przeciwne Świętemu Apostolskiemu Rzymsko-Katolickiemu Kościolowi.

Tak niech mi dopomoże Bóg i ta święta Ewangelia, której się własnymi rękami dotykam". 
